\title{
Physicochemical Treatment of Waste Water Containing Organic Materials
}

\author{
Han-Chul Lee 1* $^{*}$ \\ ${ }^{1}$ Korea Hydro \& Nuclear Power Co., Ltd Central Research Institute \\ 유기물을 함유한 폐수의 물리화학적 처리에 관한 연구 \\ 이한철 ${ }^{*}$ \\ ${ }^{1}$ 한국수력원자력(주) 중앙연구원
}

\begin{abstract}
The production of synthetic polymer compounds and ethanolamine (ETA, a pH control agent used in nuclear power plants) generates effluent that pollutes water. This study focused on the development of chemicals for the treatment of effluent and processes to reduce the COD level due to the presence of organic materials via physicochemical treatment. It was found that a mixed coagulant of $\mathrm{FeCl}_{2}$ and $\mathrm{MgCl}_{2}$ (1:1) was the most effective in treating effluent and reducing the COD level. When the mixed coagulant was injected into effluent including organic materials, the COD level was reduced by more than $80 \%$.
\end{abstract}

요 약 합성 고분자 화합물의 생산과 ethanolamine(ETA, 원자력발전소에서 사용하는 $\mathrm{pH}$ 조절제)는 수질을 오염시키는 폐수를 발생한다. 본 연구는 유기물에 의해 유발된 $\mathrm{COD}$ 를 감소시키기 위한 물리 - 화학적 처리법과 처리 약품을 개발하 였다. $\mathrm{FeCl}_{2}$ 와 $\mathrm{MgCl}_{2}$ 를 $1 / 1$ 로 혼합하여 혼합응집제를 사용함이 $\mathrm{COD}$ 제거효율이 가장 좋은 결과를 얻었다. 유기물을 함 유한 폐수처리에 복합응집제를 주입함으로써 $\mathrm{COD}$ 제거율이 $80 \%$ 이상으로 나타났다.

Key Words : Physicochemical treatment, Ferrous chloride, Magnesium chloride Mixed coagulant

\section{Introduction}

The production of synthetic polymer compounds and ethanolamine (ETA, a pH control agent used in nuclear power plants) generates effluent that pollutes water. Oil-based synthetic polymer compounds do not exist naturally and are not biodegradable. It is thus necessary to develop a method to treat the effluent. The petroleum, livestock, paper manufacturing and dyeing industries and many research laboratories discharge organic materials. The energy industry is also a culprit. Nuclear power plants also use organic materials, which are contained in lubricant and anti-corrosion materials (advanced amines) in heat exchangers and systems. Because organic materials are not considered in the treatment of effluents from nuclear power plants, it is difficult to remove these materials. Against this backdrop, several treatment methods are being studied, such as the removal of organic materials using microorganism immobilization, ultra-filtration membranes, and oxidation processes using $\mathrm{H}_{2} \mathrm{O}_{2}$ and the reduction of the COD level using the photo-Fenton method [1-3]. Effluent including organic material has a high COD level and is not biodegradable. If it is directly released into a water system, this effluent can never be naturally purified and thus causes water pollution. Although activated sludge processes are being used to treat organic materials in effluent, the material is not fully decomposed due to operational issues. Instead, it is just

${ }^{*}$ Corresponding Author : Han-Chul Lee (Korea Hydro \& Nuclear Power Co., Ltd)

Tel: +82-42-870-5666 email: leehc@khnp.co.kr

Received October 16, 2012 Revised December 14, 2012 Accepted January 10, 2013 
diluted and discharged. A recently developed approach to treat effluent containing organic materials entails the use of an electrolytic process to treat suspended and dissolved solids at the same time. However, it is difficult to apply this method industrially. Thus, the present study focused on the development of chemicals and physicochemical treatment processes to treat effluent to lower the COD caused by organic materials.

\section{Materials and Methods}

\subsection{Samples and Devices}

PVA (polyvinylalchol), a water-soluble organic material, was used to create the effluent used in these experiments. The COD level of the effluent including organic material was 900 to 2,500 ppm. Single coagulants $\left(\mathrm{FeCl}_{2}, \mathrm{FeCl}_{3}\right.$, and $\mathrm{MgCl}_{2}$ )and a mixed coagulant( $\mathrm{Fe}-\mathrm{Mg}$ ) were used as treatment chemicals for comparison. $\mathrm{NaOH}$ and $\mathrm{H}_{2} \mathrm{SO}_{4}$ were used to adjust the $\mathrm{pH}$. A polymer coagulant (anionic polyacrylamide), used as a coagulant aid, was dissolved at $0.05 \%$. To maintain consistent conditions, a jar tester was slowly operated at $300 \mathrm{rpm}$ for 1 minute and at $35-45$ rpm for 15 minutes. The SV30 was used to analyze the sludge. The $\mathrm{pH}$ and concentrations were varied during the experiment, and pre-treatment of a sample with turbidity was not implemented for easier application in the field. The official test method for water quality was adopted for the COD analysis. A UV spectrophotometer (Shumatz-1201) was used to evaluate the turbidity. To analyze the attributes of coagulants, a dynamic scattering zeta potential analyzer (Zetasizer 4, Malvern USA) was employed for

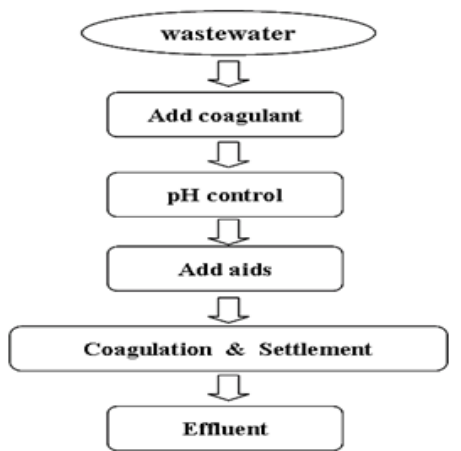

[Fig. 1] Procedure for reducing the COD level in the effluent. zeta-potential and nano size analyses, and a particle size analyzer (Beckman Coulter LS230 USA) was utilized for micro size analysis. SEM was used to visually assess the reactions. Figure 1 illustrates the experimental process.

\section{Results and Discussion}

\subsection{Experiment using single coagulants}

\subsubsection{Impact of a single coagulant}

Two commonly used coagulants, iron salt and magnesium salt, were employed. Two types of iron salt were used, iron chloride and iron sulfate. Iron chloride is an iron salt that is used as a coagulant in dyeing complexes and applications that involve large amounts of organic matter. Iron chloride is also found in the $\mathrm{Fe}-\mathrm{Al}$ mixed coagulant, which is effective in reducing the turbidity and COD level of dye effluent [4,5]. In this study, we used iron chloride and magnesium salt, which are widely utilized in enhanced coagulation processes for the efficient removal of organic matter. Magnesium salt starts to precipitate at $\mathrm{pH} 9.5$ and becomes hardened above $\mathrm{pH}$ 10.5. The precipitation of magnesium salt ends between $\mathrm{pH} 11.0$ and $\mathrm{pH} 12.5$ [6]. In this study, the $\mathrm{pH}$ of solutions of containing magnesium salt was controlled to remain alkaline.

\subsubsection{Impacts of $\mathrm{pH}$ on coagulation when using single coagulants}

The coagulation and precipitation induced by magnesium salt was evaluated; this is the most important step in the experiment. First, a sample with a COD of $1,200 \mathrm{ppm}$ was prepared by creating effluent containing water-soluble organic matter. The $\mathrm{pH}$ was maintained between 9.0 and 12.0. $\mathrm{MgCl}_{2}$ (1,000 ppm) was injected; anionic polyacrylamide was injected as a coagulant aid to facilitate coagulation and precipitation during the physicochemical treatment. After infusing the coagulant, the initial turbidity was $11 \mathrm{NTU}$ at $\mathrm{pH} 9.0$ and $63 \mathrm{NTU}$, the highest level, at $\mathrm{pH}$ 11.0. The turbidity after the reaction ended at each acidity level was below 3 NTU after applying the polymer coagulant aid. At $\mathrm{pH} 11.0$, the COD level was reduced by $58.3 \%$, the highest margin, with the highest turbidity. At $\mathrm{pH} 9.0$, the COD level was 
reduced by the lowest margin with the lowest turbidity. We found that when reactions occur, the turbidity and reaction effects appear to be correlated, and $\mathrm{Mg}^{2+}$ and the organic materials react actively.

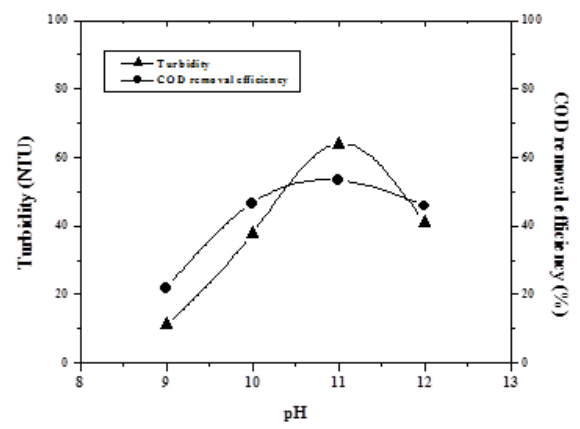

[Fig. 2] Dependence of the initial turbidity and the efficiency of the COD removal process on the $\mathrm{pH}$ during coagulation with $1,000 \mathrm{ppm} \mathrm{MgCl}_{2}$.

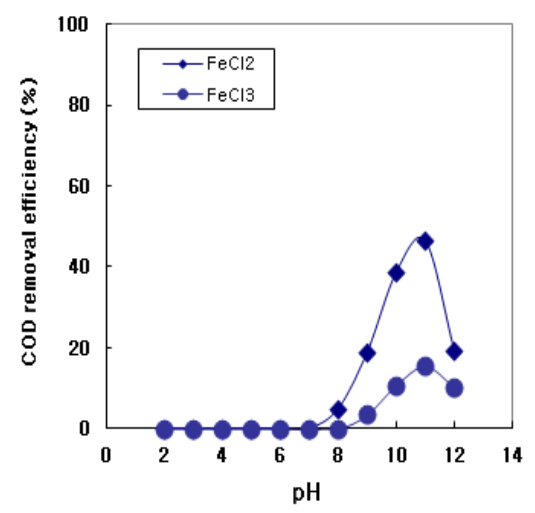

[Fig. 3] Dependence of the COD removal efficiency on the $\mathrm{pH}$ during coagulation with $1,000 \mathrm{ppm} \mathrm{FeCl}_{2}$ and $1,000 \mathrm{ppm} \mathrm{FeCl}_{3}$.

Figure 3 shows the changes in the COD caused by varying the $\mathrm{pH}$ of the effluent during coagulation with 1,000 ppm of $\mathrm{FeCl}_{2}$ and 1,000 ppm of $\mathrm{FeCl}_{3}$. Figures 2 and 3 show the same tendency. The coagulation range of $\mathrm{FeCl}_{3}$ is between $\mathrm{pH} 4.0$ and $\mathrm{pH} 11.0$, and the flock is irresolvable in the alkaline range. However, when $\mathrm{FeCl}_{3}$ was applied to the effluent, the COD level started to change at $\mathrm{pH} 9.0$ and was reduced at $\mathrm{pH} 11.0$ by $15.5 \%$, reflecting a weaker response [6]. $\mathrm{FeCl}_{2}$ started to coagulate and precipitate at $\mathrm{pH} 8.0$, and precipitation of the hydroxide was facilitated as the $\mathrm{pH}$ increased. The COD level was reduced by the largest margin at $\mathrm{pH} 11.0$, which corresponds with the result for $\mathrm{MgCl}_{2}$. At $\mathrm{pH}$ 12.0, precipitates tended to be resolved, thus reducing the COD level. These results suggest that the COD level in effluent including organic matter can be reduced by treatment with $\mathrm{FeCl}_{2}$ or $\mathrm{MgCl}_{2}$. If $\mathrm{MgCl}_{2}$ is used between $\mathrm{pH} 10.0$ and 11.0 , the COD level can be reduced effectively. $\mathrm{FeCl}_{2}$ is also effective in treating effluent containing non-biodegradable organic matter, as demonstrated by the use of $\mathrm{FeCl}_{2}$ to treat dye effluent.

\subsection{Tests with mixed coagulants}

\subsubsection{Effect of the ratio of mixed coagulants}

Based on the results with single coagulants presented in section 3.1.2, we examined whether a combination of $\mathrm{FeCl}_{2}$ and $\mathrm{MgCl}_{2}$ is more effective in reducing the COD level that either coagulant alone. Effluent was prepared using a water-soluble polymer. The tested coagulants included $\mathrm{FeCl}_{2}$ and $\mathrm{MgCl}_{2}$ combined at different ratios. Figure 4 illustrates the COD removal efficiency for the different combinations of $\mathrm{FeCl}_{2}$ and $\mathrm{MgCl}_{2}$ that were applied to $1,000 \mathrm{ppm}$ effluent at $\mathrm{pH}$ 11.0. Fast blending for 1 minute and slow blending for 15 minutes were performed. The SV30 was checked after the mixture was allowed to settle for 30 minutes. The COD level was reduced by $53 \%, 46 \%$ and $15 \%$ when $1000 \mathrm{ppm}$ of the single coagulants $\mathrm{MgCl}_{2}, \mathrm{FeCl}_{2}$ and $\mathrm{FeCl}_{3}$ were applied, respectively, and the COD level was reduced by $56 \%$ with use of the mixed coagulant $\left(\mathrm{FeCl}_{2}: \mathrm{MgCl}_{2}=1: 1\right)$. The COD level was lowered by $84 \%$ by injecting 2,000 ppm.

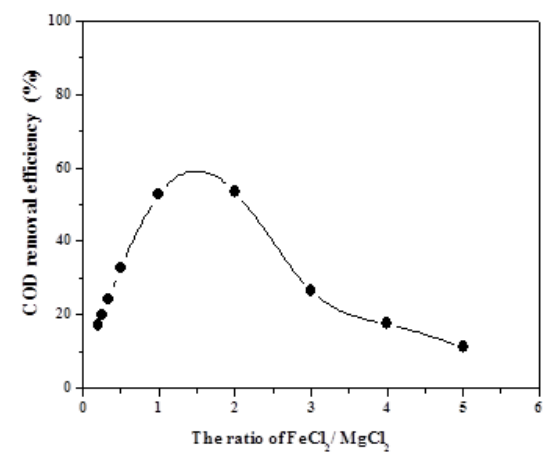

[Fig. 4] Dependence of the COD removal efficiency on the ratio of $\mathrm{FeCl}_{2}$ to $\mathrm{MgCl}_{2}$ in the mixed coagulant at $\mathrm{pH}$ 11.0. 


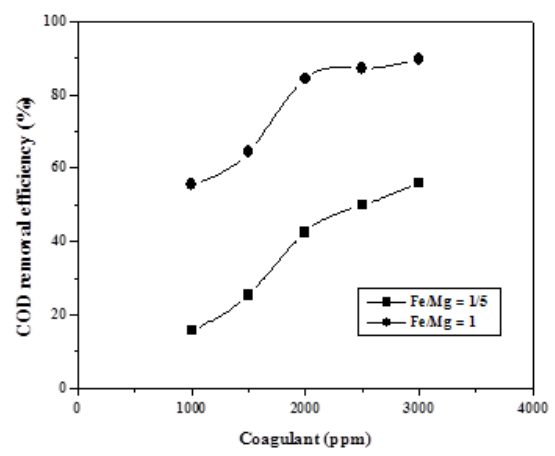

[Fig. 5] Dependence of the COD removal efficiency on the concentration of the mixed coagulant for $\mathrm{FeCl}_{2} / \mathrm{MgCl}_{2}=1, \mathrm{FeCl}_{2} / \mathrm{MgCl}_{2}=1 / 5$ at $\mathrm{pH}$ 11.0.

The SV30 was checked after the mixture was allowed to settle 30 minutes. The SV30 was 20 when the ratio of Fe to $\mathrm{Mg}$ was $1: 1$ or $2: 1$, and SV30 was 18 when the ratio between $3: 1$ and 5:1. Therefore, the amount of sludge did not appear to cause any problems. The $\mathrm{FeCl}_{2}$-to- $\mathrm{MgCl}_{2}$ ratios of $1: 1$ and $2: 1$ exhibited the same effect in reducing the COD level. In a subsequent experiment, the amount of $\mathrm{MgCl}_{2}$ was increased, while the amount of $\mathrm{FeCl}_{2}$ was left unchanged. Figure 4 illustrates the COD reduction after coagulation and precipitation that accompanied the increase in the proportion of $\mathrm{MgCl}_{2}$ from 2 to 5 . In terms of the $\mathrm{FeCl}_{2}$-to- $\mathrm{MgCl}_{2}$ ratio, the $\mathrm{COD}$ reduction effect was reduced with higher amounts of $\mathrm{MgCl}_{2}$. In addition, the COD reduction effect was also weakened when the $\mathrm{FeCl}_{2}$-to- $\mathrm{MgCl}_{2}$ ratio was higher than 2. Figure 5 shows the dependence of the COD reduction efficiency on the concentrations of the mixed coagulants $\mathrm{FeCl}_{2} / \mathrm{MgCl}_{2}=1$ and $\mathrm{FeCl}_{2} / \mathrm{MgCl}_{2}=1 / 5$, which were applied to effluent at $\mathrm{pH}$ 11.0. The mixed coagulant $\mathrm{FeCl}_{2} / \mathrm{MgCl}_{2}=1$ had a COD reduction efficiency 30 to $40 \%$ better than that of $\mathrm{FeCl}_{2} / \mathrm{MgCl}_{2}=1 / 5$.

\subsubsection{Zeta potential and Changes in $\mathrm{pH}$}

The zeta potential was determined to assess the characteristics of the mixed coagulants. The $\mathrm{pH}$ was controlled using $\mathrm{NaOH}$ and $\mathrm{H}_{2} \mathrm{SO}_{4}$ in a diluted solution of mixed coagulants. The $\mathrm{pH}$ was adjusted from 1.0 to 13.0 , and the results are provided in Figure 6. The isoelectric point was between $\mathrm{pH} 8.0$ and 9.0 and stabilized as the $\mathrm{pH}$ became more alkaline. We found that the best coagulation effect was achieved in a $\mathrm{pH}$ range of 9.0 to 12.0 because $\mathrm{FeCl}_{2}$ and $\mathrm{MgCl}_{2}$ start to coagulate at $\mathrm{pH}$ 8.0 and $\mathrm{pH} 9.5$, respectively.

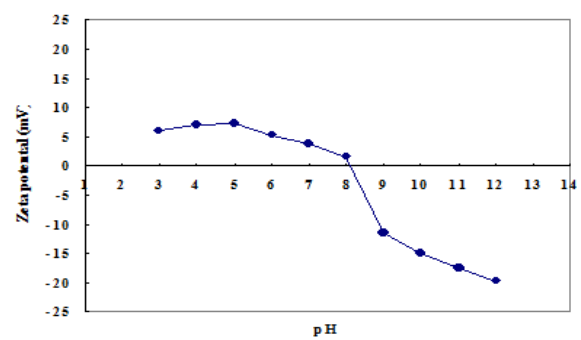

[Fig. 6] Effect of $\mathrm{pH}$ on the zeta potential of the $\mathrm{Fe} / \mathrm{Mg}$ mixed coagulant.

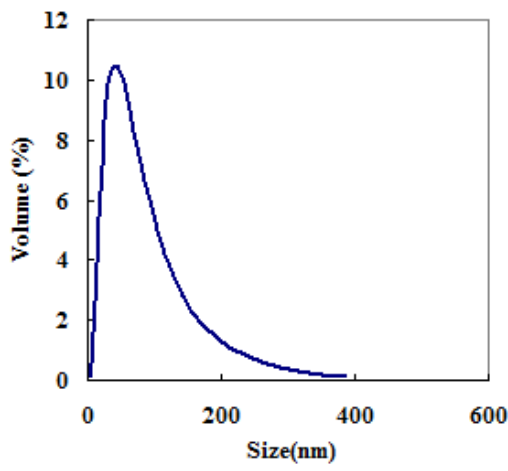

[Fig. 7] Particle size distribution of the mixed coagulant at $\mathrm{pH} 2.0$.

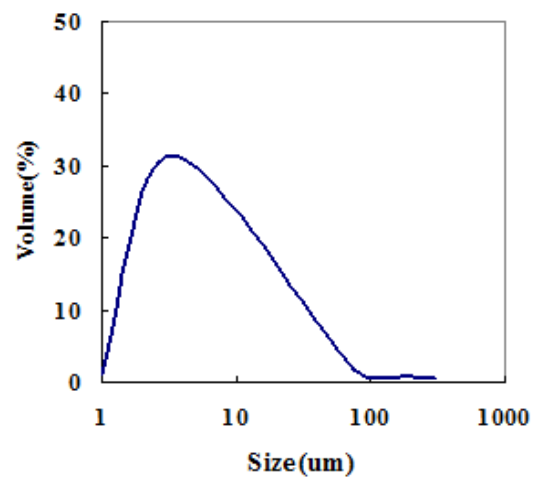

[Fig. 8] Particle size distribution of the mixed coagulant at $\mathrm{pH} 11.0$.

Moreover, the highest COD reduction efficiency was achieved between $\mathrm{pH} 10.0$ and 11.0. The particle distribution was measured with a nano size meter at $\mathrm{pH}$ 
2.0 in a stable status. The average size was $45 \mathrm{~nm}$, and the distribution is shown in Figure 7. The distribution at $\mathrm{pH}$ 11.0, which is the most suitable level for COD reduction, is presented in Figure 8 . These are the distributions of matter where $\mathrm{Fe}$ and $\mathrm{Mg}$ are formed into a hydroxide by $\mathrm{OH}-$. The size increased from $45 \mathrm{~nm}$ to $2.5 \mu \mathrm{m}$ and thus, the mixed coagulants were able to combine with the organic materials. Figure 9 shows the results for the $\mathrm{FeCl}_{2} / \mathrm{MgCl}_{2}$ mixed coagulants. The ratios are $1 / 1$ for (a), $1 / 3$ for (b), and 1/5 for (c). SEM-based observations indicated that there was no noticeable difference in the structures.

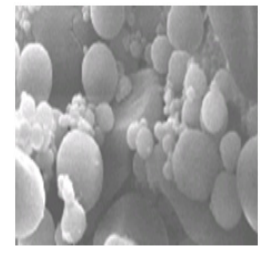

(a) $\mathrm{Fe} / \mathrm{Mg}=1: 1$

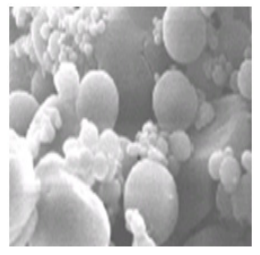

(b) $\mathrm{Fe} / \mathrm{Mg}=1: 3$

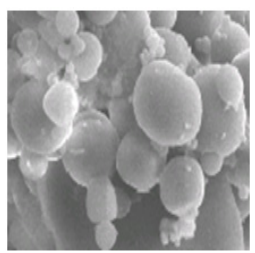

(C) $\mathrm{Fe} / \mathrm{Mg}=1: 5$

[Fig. 9] SEM images of $\mathrm{Fe} / \mathrm{Mg}$ mixed coagulants. (Magnification : 400).

\subsection{Field Test}

\subsubsection{Field Test Process}

For the field test, the $\mathrm{Fe} / \mathrm{Mg}$ mixed coagulant was applied to an effluent containing organic material using existing effluent treatment facilities. The $\mathrm{pH}$ was raised to 10.0 or 11.0 using $\mathrm{NaOH}$ in a chemical reactor. The $\mathrm{Fe} / \mathrm{Mg}$ mixed coagulant was injected at the same concentration level as in the lab experiment, and the mixture was left for 30 minutes. A polymer coagulant aid was also used for precipitation. The status of coagulation and precipitation was good. The effluent initially contained suspended solids, but the above treatment made the effluent transparent. The turbidity dropped from 85 NTU to a clearer level of 3 NTU. The result of the COD analysis was also positive. In the field test, the COD level was lowered by several chemicals $(\mathrm{NaOH}, \mathrm{Fe} / \mathrm{Mg}$ mixed coagulant, polymer coagulant aid) in the coagulation and precipitation tank. After filtering, the treated water was tested for neutralization and discharged.

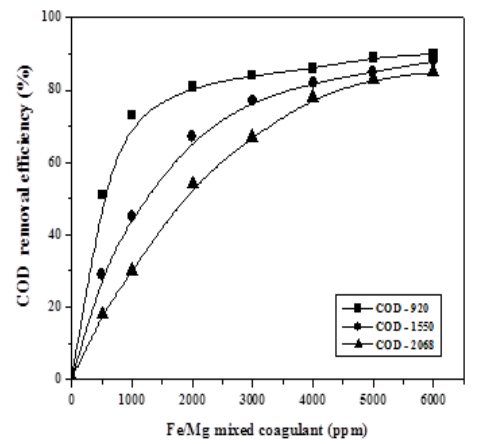

[Fig. 10] Dependence of the COD removal efficiency on the concentration of the $\mathrm{Fe} / \mathrm{Mg}$ mixed coagulant.

\subsubsection{COD reduction by $\mathrm{Mg} / \mathrm{Fe}$ mixed coagulant}

In the field test with the $\mathrm{Fe} / \mathrm{Mg}$ mixed coagulant, effluent including organic materials had a $\mathrm{pH}$ of 7 . Three COD levels were prepared: $920 \mathrm{ppm}, 1,550 \mathrm{ppm}$, and $2,068 \mathrm{ppm}$. At room temperature, $\mathrm{NaOH}$ was injected to adjust the $\mathrm{pH}$ to 11.0. The $\mathrm{Fe} / \mathrm{Mg}$ mixed coagulant was infused at concentrations that varied at regular intervals from $500 \mathrm{ppm}$ to $7,500 \mathrm{ppm}$. An agitator was set at 250 rpm for the first 5 minutes and at $40 \mathrm{rpm}$ for a further 20 minutes. A polymer coagulant was injected to enhance coagulation and precipitation. The COD level was analyzed after filtration of the precipitated sludge. Figure 10 show the COD level reduction due to the addition of the $\mathrm{FeCl}_{2} / \mathrm{MgCl}_{2}$ mixed coagulant. We found that at an initial COD level of $920 \mathrm{ppm}$ in the effluent including organic materials, the level was lowered by more than $80 \%$ when $2,000 \mathrm{ppm}$ of $\mathrm{Fe} / \mathrm{Mg}$ mixed coagulant was injected. However, an excessive amount of coagulant was required to reduce the level by more than $85 \%$.

\section{Conclusion}

A mixed coagulant containing $\mathrm{FeCl}_{2}$ and $\mathrm{MgCl}_{2}$ (1:1) was the most effective in treating effluent and reducing the COD level, which is increased by the presence of bio-degradable organic materials. In the process of 
treating organic-matter-containing effluent, the $\mathrm{pH}$ should be adjusted to between 10.0 and 11.0. For coagulation and precipitation, a coagulant aid(polyacrylamide) must be added after infusing the $\mathrm{FeCl}_{2} / \mathrm{MgCl}_{2}$ mixed coagulant. When 2,000 ppm of the mixed coagulant was injected into effluent including organic materials, the COD level was reduced by more than $80 \%$, and the turbidity dropped from $85 \mathrm{NTU}$ to a clearer level of 3 NTU.

\section{References}

[1] H. S. Choi, "A Study on Organic Compounds Removal in Leachate by Using Chemical Coagulation and Fenton Oxidation”, M.D. Thesis, Yonsei Univ. 2007 .

[2] J. H. Nam, et al, “Effects of Bacillus and Endospore Germinations on Organic Matter Removal", Journal of KSEE 29(2), pp. 169-175, 2007.

[3] J. H. Park, et al, "Application of Coagulation and Advanced Oxidation Process for the Removal of rganic Matter from Landfill Leachates", Journal of KSEE 25(7), pp. 846-852, 2003.

[4] S. W. Lee, et al," The Blending Effect of Fe-based and Al-based Coagulants on the Treatment of Dyeing Wastewater", Journal of KSEE 22(8), pp. 1495-1501, 2000.

[5] K. H. Park, et al, Theoretical Study on the Coagulation and Flocculation", Journal of Environmental Research 2(1), pp.1A-10A, 2000.

[6] B. H. Tan, et al,"Removal of Dyes and Industrial Dye Wastes by Magnesium Chloride",Water Research 34(2), pp.597-601, 2000.

DOI: http://dx.doi.org/10.1016/S0043-1354(99)00151-7

\section{Han-Chul Lee}

[Regular member]

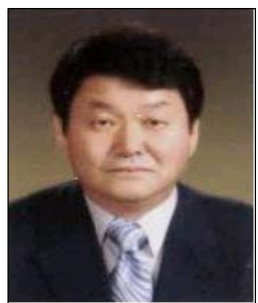

Feb. 2007 : Inha Univ. Chemical Eng. ph. D

- Apr. $2007 \sim$ Current : KHNP Central Research Institute Principal Researcher

$<$ Research Interests $>$

Nuclear Water Chemistry, Surface Engineering 